\title{
DENTIN REPARATIF DAN GROWTH FACTOR YANG BERPERAN DALAM DENTINOGENESIS REPARATIF
}

\author{
(REPARATIVE DENTIN AND THE ROLE OF GROWTH FACTOR IN REPARATIVE \\ DENTINOGENESIS)
}

\author{
Essie Octiara \\ Departemen Ilmu Kedokteran Gigi Anak \\ Fakultas Kedokteran Gigi Universitas Sumatera Utara \\ Jl. Alumni no 2 Medan \\ E-mail: eoctiara@gmail.com
}

\begin{abstract}
Reparative dentin is defined as a tertiary dentin matrix secreted by a new generation of odontoblast-like cell in response to an appropriate stimulus after the death of the original postmitotic odontoblast. Reparative dentinogenesis involves progenitor cell from the pulp, must be recruited and induced to differentiate into odontoblast-like cell before its secretion may be upregulated to form the reparative dentin matrix. One of which plays a role in the reparative dentinogenesis is growth factors, which act as a regulatory cell functions such as proliferation, differentiation and matrix synthesis. Different types of growth factors that play a role in the regeneration of complex pulp include Transforming Growth Factor- $\beta$ (TGFS- $\beta$ ), Bone Morphogenetic Protein ( BMPs ), Platelet Derived Growth Factor ( PDGF ), Insuline Like Growth Factor ( IGF ) and fibroblast growth factor ( FGFs ).
\end{abstract}

Key words: reparative dentin, odontoblast-like cell, growth factor

\begin{abstract}
Abstrak
Dentin reparatif adalah matriks dentin tersier yang disekresikan oleh sel odontoblast-like cell baru, untuk merespons stimulus yang kuat setelah terjadinya kematian odontoblast postmitotic. Dentinogenesis reparatif melibatkan sel progenitor dan adanya induksi diferensiasi dari odontoblast-like cell sebelum terjadinya sekresi matrix dentin reparatif. Salah satu yang berperan dalam dentinogenesis reparatif adalah growth factor, yang bertindak sebagai regulasi beberapa fungsi sel seperti proliferasi, diferensiasi dan sintesis matriks. Berbagai jenis growth factor yang berperan dalam regenerasi kompleks pulpa antara lain, Transforming Growth Factor- $\beta$ (TGFS- $\beta$ ), Bone Morphogenetic Protein (BMPs), Platelet Derived Growth Factor (PDGF), Insuline Like Growth Factor (IGF) dan Fibroblast Growth Factor (FGFs).
\end{abstract}

Kata kunci: dentin reparatif, odontoblast like cell, growth factor

\section{PENDAHULUAN}

Seorang dokter gigi harus mampu menjaga dan mempertahankan vitalitas pulpa gigi, agar kehilangan gigi dapat dihindari. Pulpa gigi kadang dapat terkena stimuli eksternal seperti infeksi karies atau trauma injuri. Pada saat dokter gigi menemukan karies gigi dengan pulpa vital dan reversibel, maka pada kasus tersebut akan dilakukan pembuangan enamel dan dentin yang terinfeksi, dan kemudian dilakukan perawatan pulp capping atau pulpotomi. Biomaterial pulp capping dan pulpotomi seperti kalsium hidroksida, diterima sebagai prosedur efektif untuk menginduksi pemulihan jaringan pulpa, dimulai dari fase inisial berupa proses apoptosis odontoblast dan sel pulpa yang telah mati, diikuti dengan dentinogenesis reaksioner dan reparatif dalam fase late. Dentin reaksioner dibentuk oleh odontoblast yang survive, sedangkan dentin reparatif dibentuk oleh odontoblastlike cell terdiferensiasi dari stem sel pulpa gigi atau residual pulpa gigi. ${ }^{1}$

Dentin reparatif adalah matriks dentin tersier yang disekresikan oleh sel odontoblast-like cell baru, untuk merespons stimulus yang kuat setelah terjadinya kematian odontoblast postmitotic original yang bertanggung jawab atas sekresi dentin primer atau 
sekunder. Respons dentin reparatif berada pada sisi pulpa yang terekspos, hal ini karena hilangnya odontoblast dan diperlukannya pembentukan jembatan dentin (dentinal bridge) pada daerah tersebut. Dentinogenesis reparatif melibatkan sequensi (lebih kompleks) kejadian biologik yang lebih langkah dibandingkan dentinogenesis reaksioner, karena melibatkan sel progenitor dan adanya induksi diferensiasi dari odontoblastlike cell sebelum terjadinya sekresi matrix dentin reparatif. Salah satu yang berperan dalam dentinogenesis reparatif adalah growth factor, yang bertindak sebagai regulasi beberapa fungsi sel seperti proliferasi, diferensiasi dan sintesis matriks. ${ }^{2}$

Pada dasarnya growth factor akan dilepaskan pada matriks dentin sebagai kompensasi injuri jaringan dan prosedur restorasi. Pada kejadian karies, difusi asam dari metabolit bakteri yang masuk ke dalam jaringan gigi akan menyebabkan demineralisasi, dan pada keadaan ini akan dilepaskannya komponen matriks ekstraseluler soluble termasuk growth factor. Komponen ini akan berdifusi pada pulpa secara langsung kemudian berinteraksi dengan sel. Kejadian demineralisasi akibat proses karies ini akan menyebabkan dilepasnya growth factor selama periode waktu yang cukup lama, sehingga dapat memfasilitasi untuk terjadinya signalling sel. ${ }^{2,3}$

Growth factor adalah grup protein yang dapat menginduksi proliferasi sel dan diferensiasi sel dengan mengikat pada reseptor permukaan sel. Berbagai jenis growth factor yang berperan dalam regenerasi kompleks pulpa, antara lain Transforming Growth Factor- $\beta$ (TGFS- $\beta$ ), Bone Morphogenetic Protein (BMPs), Platelet Derived Growth Factor (PDGF), Insuline Like Growth Factor (IGF) dan Fibroblast Growth Factor (FGFs). ${ }^{4}$ Tujuan penulisan makalah ini untuk membahas mengenai dentinogenesis reparatif dan growth factor yang berperan dalam proses pembentukan dentin tersebut. Mempelajari growth factor akan memberikan dasar untuk dimengertinya mekanisme biologis dari regenerasi jaringan dalam dentin-pulpa kompleks dan efek perawatan endodontik.

\section{DENTIN REPARATIF}

Dentin reparatif adalah matriks dentin tersier yang disekresikan sel odontoblast like cell yang berasal dari sel mesenkim yang belum terdiferensiasi, merupakan respons tubuh terhadap stimulus yang kuat. ${ }^{2}$ Pemulihan (repair) dentin dihubungkan dengan meningkatnya vaskularisasi dan inisiasi respons innate imun pada area tersebut. Hal ini dihubungkan dengan kemampuan sel pulpa melakukan sekresi growth factor, yang akan memulai stimulasi diferensiasi sel dan neovaskularisasi. ${ }^{5}$

Ada tiga tahap dentinogenesis reparatif: (1) recruitment sel progenitor, (2) signalling diferensiasi odontoblastlike cell, dan (3) regulasi sekresi matriks oleh sel. Sel mesenkim yang belum terdiferensiasi, berada dalam cell rich zone Höhl berdekatan dengan odontoblast layer merupakan sel progenitor. Sel progenitor bersifat pluripoten, yaitu memiliki kapasitas untuk berdiferensiasi menjadi bermacam-macam jenis sel sesuai dengan kebutuhan yang timbul. Sel ini merupakan sel yang pertama kali membelah ketika terjadi cedera. Sel tersebut dapat menjadi fibroblas maupun odontoblas. Selama peradangan, sel-sel tersebut dapat berdiferensiasi menjadi makrofag atau sel resorpsi (dentinoklas). ${ }^{2}$

Pada dentinogenesis reparatif, migrasi sel progenitor pada pulpa ke arah sisi cedera memerlukan kemampuan kemotaktik. Komponen matriks dentin pada pulpa yang memiliki kemampuan kemotaktik antara lain perisit dan TGF- $\beta 1$ (kemotaktik untuk fibroblast, makrofag, neutrofil, dan monosit selama penyembuhan jaringan luka). ${ }^{2}$

Bersamaan dengan migrasinya sel progenitor pada sisi cedera, signalling diferensiasi dari odontoblastlike cell harus sudah terjadi sebelum sekresi dentin reparatif dimulai. Dalam hal ini growth factor dan sitokin yang berperan di dalam signalling diferensiasi odontoblast. Growth factor yang paling banyak dibicarakan adalah TGF- $\beta$ s yang berasal dari dentin matriks, kelompok growth factor ini hadir dalam matriks sebagai protein matriks dengan kandungan bioaktif yang potensial. $^{2}$

Matriks yang disekresikan selama dentinogenesis tersier dapat berbentuk regular (tubular matriks) sampai berbentuk atubular matriks (displastik) dan kadangkadang disertai adanya inklusi seluler seperti fibrodentin., ${ }^{2,6}$ Pada beberapa dentin reparatif, kadangkadang menunjukkan tampilan osteodentin. ${ }^{6}$ Bervariasinya morfologi matriks ini dihubungkan dengan morfologi dan sekretori dari odontoblast-like cell yang terlibat di dalam sekresi, yang memiliki struktur matriks dan komposisi yang berbeda. ${ }^{2}$ Struktur dentin reparatif bersifat lebih irregular, kurang mineralisasi, lebih lunak dan lebih banyak berisi material organik dibanding dentin primer. ${ }^{6}$

Pada sisi tereksposnya pulpa, dentin reparatif akan terdeposisi dengan membentuk jembatan dentin. Pada beberapa jembatan dentin yang terbentuk, kadang ditemukan ketidaksempurnaan jembatan dentin yang disebut dengan tunnel defect, yaitu adanya multipel perforasi yang dapat memberikan komunikasi antara pulpa dan bahan capping. Adanya tunnel defect ini dapat mencegah penutupan yang hermetis dari pulpa, sehingga dapat memungkinkan infeksi bakteri 
secara rekuren dari mikroleakage tersebut. ${ }^{2}$

\section{FUNGSI GROWTH FACTOR DALAM DENTINO- GENESIS}

Growth factor dan sitokin merupakan kunci molekul signalling yang akan mengontrol dan meregulasi seluler yang terlibat dalam perkembangan, homeostatis dan pemulihan jaringan. Mereka juga berperan dalam menginisiasi dan meregulasi pemulihan jaringan pada pulpa gigi. Peran dan aktivitas mereka telah dieksplor dalam berbagai penelitian, berguna untuk identifikasi pemulihan biologik dan pendekatan tissue engineering dalam perawatan pulpa dan penyakit periradikuler. ${ }^{2}$

Growth factor merupakan molekul peptida yang bertanggung jawab untuk signalling berbagai proses seluler yang mengikuti dental injuri. Growth factor berfungsi sebagai signal transmiter antara fungsi sel yaitu sebagai stimulator dan atau inhibitor dari pertumbuhan dan juga sebagai modulator diferensiasi. Growth factor akan meregulasi gen yang mengontrol proliferasi sel, diferensiasi sel atau produk sekretori sel. ${ }^{3}$ Dalam menimbulkan efek, growth factor bekerja dengan mengikat reseptor pemukaan sel spesifik tertentu, dengan menggunakan signal tranduser inti sel melalui berbagai jalur transduksi. ${ }^{7}$

TGF- $\beta$ famili merupakan growth factor yang ditemukan pada dentin, dan berperan pada signalling diferensiasi odontoblast selama perkembangan gigi, dan berperan penting sebagai molekul signalling repair. Dentin matriks berisi molekul bioaktif dengan potensi signalling sel yang akan dilepaskan dalam lingkungan pulpa selama injuri jaringan. Growth factor ini berisi soluble dan insoluble kompartemen jaringan dari matriks, dan mereka dilepaskan atau terekspos akibat kondisi tertentu. ${ }^{3,6}$

Growth factor dalam dentin matriks kebanyakan berasal dari sel odontoblast, dan setelah disekresikan, growth factor berinteraksi dengan matriks ekstraseluler atau komponen mineral dentin. Interaksi dengan komponen matriks adalah sangat penting dalam memproteksi aktivitas biologik growth factor karena half-life protein ini hanya beberapa menit ketika mereka keluar dalam serum.,

Regenerasi jaringan pulpa memerlukan jaringan pembuluh darah yang baik, oleh karena itu strategi vasculogenesis merupakan tantangan sendiri di dalam tissue engineering. Adanya angiogenik growth factor dalam dentin matriks merupakan hal penting dalam stimulasi pembentukan kapiler baru pada sisi pemulihan jaringan. Vascular Endothelial Growth Factor (VEGF) adalah prototip faktor pro-angiogenik (stimulasi angiogenesis), sehingga dapat meningkatkan terjadinya vaskularisasi baru. ${ }^{8}$

\section{TRANSFORMING GROWTH FACTOR- $\beta$ (TGF- $\beta$ )}

Transforming growth factor- $\beta$ (TGF- $\beta$ ) termasuk dalam TGF- $\beta$ super famili. TGF- $\beta$ super famili terdiri atas lebih dari 40 protein yang berlainan, dapat diklasifikasikan menjadi 3 grup besar yaitu grup pertama TGF- $\beta \mathrm{s}$ (isoform TGF- $\beta 1$, TGF- $\beta 2$, TGF- $\beta 3$ dan TGF- $\beta 5$ ), grup kedua BMP (bone morphogenetic protein) yang terdiri atas BMP-2, BMP-3, BMP-4, BMP-5, BMP-6, BMP-7 dan BMP-8) dan grup ketiga activins/ inhibins. Masing-masing grup ini mampu meregulasi proses seluler termasuk proliferasi sel, diferensiasi, motilitas, adhesi dan kematian. TGF- $\beta$ berperan dalan homeostatis dan repair jaringan dalam tubuh. ${ }^{6}$

Odontoblast mengekspresikan ketiga isoform dari TGF- $\beta$ (TGF- $\beta 1,2,3)$. Hanya TGF- $\beta 1$ yang mampu berinteraksi dengan proteoglikan dari dentin matriks, decorin, dan biglikan, sedangkan bentuk isoform lain menunjukkan afinitas yang kurang pada matriks. ${ }^{3,6}$

TGF- $\beta$ juga membantu mengurangi respons inflamatori dalam pulpa. Growth factor ini dilepaskan selama terjadinya dental injuri. Adanya iritasi bakteri dan inflamasi pulpa pada karies yang mencapai pulpa, juga akan memodifikasi pelepasan growth factor ini beserta aktivitasnya selama pemulihan/ repair. ${ }^{3,6}$ TGF- $\beta$ juga dapat menginduksi terjadinya angiogenesis. $^{5}$

Aplikasi langsung TGF- $\beta 1$ pada odontoblast dengan pulpa tereskpos yang dilakukan pada kultur jaringan gigi, menunjukkan kemampuan growth factor ini sebagai signal dentinogenesis reaksioner. Pada penelitian in vivo, TGF- $\beta 1$ menunjukkan meningkatkan pembentukan dentin reparatif. TGF- $\beta 2$ menstimulasi sintesis dan mendeposisi matriks. TGF- $\beta 3$ mampu menstimulasi diferensiasi adult stem sel pulpa pada sel odontoblast dalam kultur gigi. Penelitian lain menemukan bahwa TGF- $\beta 2$ dapat menghambat pertumbuhan dan diferensiasi stem sel pulpa. Berbagai respons TGF- $\beta 2$ pada sel pulpa gigi dapat dikaitkan dengan multipel aktivasi signal pathway, sehingga signal memberikan respons yang berbeda. ${ }^{5}$

\section{PLATELET DERIVED GROWTH FACTOR (PDGF)}

PDGF dilepaskan oleh platelet, berfungsi dalam promosi angiogenesis proliferasi sel. PDGF memiliki 4 isoform homodimer yaitu AA, BB, CC dan DD; dan heterodimer PDGF-AB. ${ }^{9}$

Kemotaksis dan proliferasi dari mesekim stem/ sel progenitor dapat diinduksi oleh PDGF pada sisi injuri. Pada keadaan trauma, hemorrhage diikuti pembentukan blood clot pada pulpa. Platelet pada blood 
clot melepaskan $\alpha$-granul berisi PDGFs dan menarik neutrofil dan makrofag. Sel-sel ini memainkan peran kunci dalam penyembuhan awal luka dengan memproduksi molekul signal untuk pembentukan jaringan granulasi. $^{9}$

Isoform PDGF-AB dan $\mathrm{BB}$ dapat menstimulasi ekspresi dentin sialoprotein (DSP), namun PDGF memiliki efek yang tidak besar dalam pembentukan dentin-like nodule pada sel pulpa gigi yang diisolasi dari gigi insisif bawah tikus. Pada kultur, PDGFs menstimulasi sel proliferasi dan mensintesis dentin matriks protein, namun ia juga menghambat akti-vitas alkalin fosfatase (ALP) pada sel pulpa gigi. Ekspresi DSP dihambat oleh PDGF-AA, namun ditingkatkan oleh PDGF-AB dan PDGF-BB, hal ini menujukkan efek PDGFs pada diferensiasi odontoblastik tergantung pada bentuk dimernya. ${ }^{9}$

PDGF meningkatkan proliferasi fibroblast pada pulpa gigi manusia. PDGF-BB dapat meningkatkan ekspresi VEGF dalam osteoblast dan mempromosikan angiogenesis pada sisi pulpa gigi yang injuri. Secara in vivo, PDGF mempromosikan de novo pembentukan dental-pulp-like tissue pada gigi manusia, seperti yang terjadi pada tikus. ${ }^{9}$

\section{VASCULARENDOTHELIAL GROWTHFACTOR (VEGF)}

Vascular endothelial growth factor (VEGF) adalah regulator angiogenesis dan dapat meningkatkan permeabilitas vaskular. ${ }^{10}$ VEGF menginduksi kemotaksis, proliferasi dan diferensiasi sel pulpa gigi manusia. VEGF terdiri atas 6 jenis yaitu: VEGF A, VEGF B, VEGF C, VEGF D, VEGF E dan platelet derived growth factor. VEGF A dan B berhubungan erat dengan angiogenesis. ${ }^{5}$

Pada dentin matriks manusia mengandung VEGF. Kehadiran VEGF pada dentin dan respons sel pulpa gigi terhadap VEGF meningkatkan kemungkinan kehadiran sel progenitor endotel pada pulpa bersama dengan progenitor odontoblast dan sel neural. Mengingat peran sel progenitor endotel dalam vaskularisasi selama gerenerasi jaringan, kemungkinan VEGF dan sel endotel vaskular sangat penting untuk regenerasi dentin. ${ }^{10}$

\section{BONE MORPHOGENETIC PROTEINS (BMPS)}

Bone morphogenetic proteins (BMPs) secara original diisolasi dari matriks tulang terdemineralisasi, namun growth factor ini juga ditemukan di dalam dentin. BMP dapat menginduksi stem sel dan sel mesenkim diferensiasi menjadi sel osteogenik agar dapat menghasilkan tulang. ${ }^{11,12}$

BMPs terdiri atas rantai dimer yang dihubungkan dengan ikatan disulfida, rantai dimer ini berfungsi menginduksi tulang. BMPs aktif yaitu sebagai molekul homodimer (dua rantai identik) dan heterodimer (dua rantai berbeda). Lima belas BMPs telah dapat diindentifikasi dan dibagi menjadi subfamili berdasarkan kemiripan sequensi asam aminonya. BMP memiliki struktur $40-50 \%$ mirip dengan TGF- $\beta$, oleh karena itu BMP termasuk superfamili dari TGF- $\beta{ }^{12}$

BMP terlibat dalam perkembangan gigi, dan ekspresi BMP meningkat selama akhir diferensiasi odontoblast. Penelitian menunjukkan, BMP-2 dapat menginduksi ekspresi mRNA dari sialophosphoprotein, ia merupakan marker diferensiasi odontoblast, dan juga menginduksi sejumlah besar dentin reparatif pada pulpa yang diamputasi secara in vivo. BMP-2 juga dapat menginduksi pembentukan osteodentin pada gigi hewan musang. ${ }^{13}$

Penelitian lain menemukan recombinant human BMP2, BMP4 dan BMP7 dapat menginduksi pembentukan dentin reparatif. ${ }^{11}$ Peneliti menggunakan recombinant BMP-7 sebagai agent capping pada hewan babi kecil, dan diperoleh hasil adanya pembentukan barier dentin lebih tebal pada grup yang dirawat dengan recombinant BMP-7 dibanding grup kontrol yang dirawat dengan $\mathrm{CaOH}_{2} .{ }^{12}$ Peneliti lain menggunakan recombinant BMP-2 sebagai agent capping pada pulpa gigi anjing, dan pada gigi tersebut dapat diamati pembentukan barier dentin setelah satu minggu, dibanding kontrol yang dirawat dengan $\mathrm{CaOH}_{2}$ atau yang hanya dirawat dengan BMP-2. ${ }^{12}$

\section{INSULIN LIKE GROWTH FACTORS (IGF)}

Insulin like growth factor (IGF) adalah growth factor yang bekerja dalam berbagai proses pertumbuhan dan diferensiasi dan juga bekerja dalam kondisi patologis. IGF adalah polipeptida rantai tunggal dengan target reseptor pada permukaan sel. IGF famili mencakup 3 ligan (Insulin, IGF-I dan IGF-II), 3 reseptor permukaan sel (Insulin, IGF-I dan IGF-II/ Mannose-6-fosfat reseptor), dan sedikitnya 6 afinitas tinggi IGF-binding protein (IGFBPs) yang akan mengikat sirkulasi IGFs dan memodulasi aksi biologik growth factor tersebut. ${ }^{7}$

IGF terlibat dalam beberapa struktur periodontal, pertumbuhan gigi dan perkembangan, termasuk akumulasi produk gen enamel spesifik yang terlibat dalam biomineralisasi enamel. IGF-I bersifat kemotaktik untuk sel yang berasal dari PDL (periodontal ligamen) dan memiliki efek kuat pada mitogenesis dan sintesis protein sel PDL. Baik IGF-1 dan IGF-II ditemukan pada sejumlah besar tulang, dan IGF-II lebih banyak berada dalam matriks tulang. IGF-I diproduksi oleh osteoblast yang menstimulasi pem- 
bentukan tulang dengan cara menginduksi proliferasi sel, diferensiasi dan biosintesis kolagen tipe I. ${ }^{7}$

IGFs bersama dengan growth factor lain mampu memulihkan jaringan pulpa gigi, dentinogenesis reparatif dan juga menambah proses pemulihan tulang. IGF-I yang terjebak dalam struktur matrik dentin selama proses sintesis, sekresi dan mineralisasi, dapat dilepaskan ke dalam pulpa gigi setelah injuri pada dentin-pulpa kompleks, dan growth factor ini akan memulai stimulasi proses pemulihan. ${ }^{7}$

Penelitian eksperimental pada hewan, menunjukkan adanya hubungan IGF-I dalam proses pemulihan pulpa gigi dan dentinogenesis reparatif. Aktivitas IGF-1 dimodulasi oleh IGF binding protein spesifik. Aplikasi IGF-I dengan heparin meningkatkan ekspresi bone morphogenetic protein $4 \mathrm{mRNA}$ yang diisolasi dari papila gigi tikus. Saat IGF-I yang dikombinasikan dengan platelet derived growth factor (PDGF) ditambahkan dengan $\mathrm{CaOH}$, terjadi peningkatan yang signifikan terhadap pemulihan perforasi apikal pada anjing. Tambahan lagi, tidak ditemukannya reaksi inflamasi pada jaringan apikal dan jaringan ikat di sekitar pembentukan jaringan keras baru tersebut.?

IGF akan meningkatkan aktivitas alkalin fosfatase pada kultur sel pulpa gigi, dan meningkatkan pembentukan dentin reparatif secara in vivo. ${ }^{14}$ Recombinant human IGF-1 bersamaan dengan membran kolagen, dapat menginduksi terjadinya jembatan dentin yang sempurna dan juga pembentukan dentin tubular. $^{10}$

\section{FIBROBLAST GROWTH FACTOR (FGF)}

Human fibroblast growth factor (FGF) famili terdiri atas 22 protein yang bertugas meregulasi sejumlah proses fisiologis pada organisme, dan memiliki 4 transmembran FGF- reseptor tirosine kinase (FGFR1-4). ${ }^{15}$ FGF-2 secara normal tersimpan dalam matriks ekstraseluler dan dilepaskan oleh enzim degradasi dari molekul ECM. ${ }^{5,6}$ Growth factor ini berperan dalam kondisi fisiologis seperti pembentukan enamel dan dentin pada benih gigi, dan juga pada kondisi patologis. ${ }^{16}$ FGF-2 berperan juga dalam aktivitas angiogenik dan mempunyai kemampuan mitogenik pada sel mesenkim. ${ }^{5}$

Penelitian implantasi FGF-2 atau hidrogel gelatin yang digabung dengan FGF-2 yang diletakan pada defek dentin setelah dilakukannya amputasi pulpa menemukan bahwa, pelepasan FGF-2 mempercepat pembentukan dentin reparatif pada sisa pulpa gigi. Pelepasan FGF-2 dari hidrogel gelatin menginduksi pembentukan partikel seperti dentin (dentin-like particle) dalam proliferasi pulpa pada bagian defek dentin di atas pulpa yang diamputasi, dan penemuan ini merupakan pendekatan terapi yang baru untuk dentin-pulpa kompleks. Namun dentin-like particle yang terbentuk berbentuk porus, sehingga kurang ideal sebagai struktur dentin regenerasi. Hal ini kemungkinan karena dosis pelepasan FGF-2 yang kurang, oleh karena itu penelitian lanjutan dilakukan. Setelah dilakukan peningkatan dosis FGF-2 pada hidrogel gelatin, maka terbentuk jaringan terkalsifikasi seperti yang diharapkan. Dapat diambil kesimpulan, dosis FGF-2 yang dilepaskan dari hidrogel gelatin memiliki pengaruh pada struktur jaringan kalsifikasi yang terinduksi dalam proliferasi pulpa pada defek dentin. ${ }^{16}$

\section{PEMBAHASAN}

Sebelum dibentuknya dentin reparatif, sel pulpa gigi akan mensekresikan berbagai growth factor yang dapat menginduksi angiogenesis (baik secara langsung atau tidak langsung yang dibantu oleh regulasi ekpresi growth factor lain) yaitu FGF (FGF2 ), TGF- $\beta$, PDGF, VEGF dan TNF-alpha. Dari growth factor tersebut, VEGF merupakan growth factor yang paling berperan penting dalam angiogenesis, baik secara fisiologis maupun patologis. ${ }^{5}$ FGF-2 bertindak sebagai faktor stimulasi awal pada pembentukan jaringan granulasi selama pemulihan jaringan. ${ }^{9}$

Gonçalves (2007) melaporkan bahwa odontoblastlike cell dan sel pulpa belum terdiferensiasi mengekspresikan tingkat basal yang tinggi dari VEGF dalam in vitro, dan endotoksin bakteri juga akan meningkatkan regulasi ekspresi VEGF dalam odontoblastlike cell melalui signalling pathway TLR4. Diamati juga bahwa rhVEGF165 dapat menginduksi respons angiogenik pada pulpa, dengan menunjukkan peningkatan kepadatan microvessel. Hal ini menggambarkan bahwa pada keadaan pulpa gigi yang parah, sel pulpa masih dapat merespons stimulus angiogenik dengan dimediasi oleh VEGF. ${ }^{9}$

TGF- $\beta$ ditemukan dalam matrik tulang dalam jumlah yang lebih tinggi dibanding BMPs, dan TGF- $\beta$ lebih diklasifikasikan sebagai sitokin dibanding morphogenes. Disamping itu BMP-2 akan menginduksi atau meningkatkan ekspresi alkalin fosfatase dan osteocalsin (marker diferensiasi osteoblast), sedangkan TGF- $\beta 1$ bekerja menghambat ekspresi osteocalsin dan aktivitas alkalin fosfatase. ${ }^{12}$

Penelitian mengenai perbandingan efek recombinant bFGF, IGF-II dan TGF- $\beta 1$ pada sel pulpa gigi hewan anjing telah dilakukan. Hasil yang diperoleh TGF- $\beta 1$ lebih mampu menginduksi odontoblast dibanding FGF dan IGF-II. ${ }^{5}$

Beberapa growth factor dilepaskan pada dentin atau disekresi oleh sel pulpa memiliki potensi efek 
regeneratif, termasuk TGF famili, BMPS, protein non kolagen (DSP dan DMP-1), VEGF dan human IGF. TGF dapat mengekspresikan secara kuat dari BSP (bone sialoprotein) dan DSP (dentin sialophosphoprotein) pada gigi molar tikus dengan pulpa terbuka setelah diberi MTA. ${ }^{5}$

Disimpulkan bahwa sel progenitor yang bertanggung jawab pada pembentukan dentin reparatif adalah sel mesenkim belum terdiferensiasi yang berada dalam sel pulpa, yang kemudian akan berubah menjadi odontoblast-like cell. Salah satu yang berperan dalam signalling diferensiasi odontoblast-like cell dan regulator dalam sekresi matriks adalah growth factor. Beberapa growth factor yang berperan dalam pembentukan dentin reparatif, antara lain Transforming Growth Factor (TGFS), Bone Morphogenetic Protein (BMPs), Insuline Like Growth Factor (IGF) dan Fibroblast Growth Factor (FGFs).

\section{Daftar Pustaka}

1. Kitamura C, Nishihara T, Terashita M, Tabata Y, Jimi E, Washio A, et al. Regeneration approaches for dental pulp and periapical tissues with growth factors, biomaterials, and laser irradiation. Polymers 2011; 3: 1776-93.

2. Hargreaves KM, Goodis HE, Tay FR. $2^{\text {nd }}$ ed., Dental pulp. Chicago: Quintessence Publishing Co., 2012: 34-46.

3. Smith AJ, Patel M, Graham L, Sloan AJ, Cooper PR. Dentin regeneration: key roles of stem cells and molecular signalling. Oral Biosci Med 2005; 2 (2/3): 127-32.

4. Zhang W, Yelick P. Vital pulp therapy-current progress of dental pulp regeneration and revascularization. <http://dx.doi.org/10.1155/ 2010 /856087> (1 April 2015).

5. Sharma S, Vimal Sikri V, Sharma NK, Sharma VM. Regeneration of tooth pulp and dentin: trends and advances. Annals of Neurosciences 2010; 17 (1): $1-5$.

6. Haniastuti T, Nunez P, Djais AA. The role of transforming growth factor beta in tertiary dentinogenesis. Dent J (Maj Ked Gigi) 2008; 41 (1): 15-20.

7. Sudhakar U, Ramakrishnan, Anand PB. Emerging role of the insulin like growth factors in pulp healing, reparative dentinogenesis and periodontal regeneration. J Conservative Dent 2006; 9 (2): 78-80.

8. Demarco FF, Conde MCM, Cavalcanti B, Casagrande L, Sakai V, Nor JE. Dental pulp tissue engineering. Braz Dent 2011; 22(1): 3-13.

9. Gonçalves SB, Dong Z, Bramant, Holland, Smith AJ, Nör JE. Tooth slice-based models for the study of human dental pulp angiogenesis. JOE 2007; 33 (7): 811-4.

10. Saraf KK. An endodontic perspective on dentin regenerative proteins and tissue engineering. Chhattisgarh J Health Sciences 2013;1(1): 57-60.

11. Gandhi A, Gandhi T, Madan N. Dental pulp stem cells in endodontic research: a promising tool for tooth tissue engineering. RSBO 2011; 8(3): 335-40.

12. Granjeiro JM, Oliveira RC, Bustos-Valenzuela JC, Sogayar MC, Taga R. Bone morphogenetic proteins: from structure to clinical use. J Braz Med and Biol Res 2005; 38: 1463-73.

13. Zivkovic P, Petrovic V, Najman S, Stefanovic V. Stem cell-based dental tissue engineering. Scient World J 2010; 10: 901-16.

14. Pauly K, Fritz K, Furey A, Lobner D. IGF-1 and TGF- $\beta$ stimulate cystine/glutamate exchange activity in dental pulp cells. Endod 2011; 37(7): 943-7.

15. Krejci P, Prochazkova J, Bryja V, Kozubik A, Wilcox WR. Molecular pathology of the fibroblast growth factor family. Hum Mutat 2009; 30(9): 124-55.

16. Ishimatsu $\mathrm{H}$, Kitamura $\mathrm{C}$, Morotomi $\mathrm{T}$, Tabata $\mathrm{Y}$, Nishihara $\mathrm{T}$, Chen $\mathrm{K}$, et al. Formation of dentinal bridge on surface of regenerated dental pulp in dentin defects by controlled release of fibroblast growth factor-2 from gelatin hydrogels. JOE 2009; 35 (6): 858-65. 